\title{
Maasai Mara University Impact in Knowledge Sharing on Renewable Energy for Sustainable Development: Narok County, Kenya
}

\author{
Bulitia Godrick Mathews* Rogers Obare Matikho Rahab Koech Aloys Mosima Osano \\ Maasai Mara University, 861-20500, Narok, Kenya
}

\begin{abstract}
Universities serve as a hub in knowledge generation which is the main driver for a sustainable economic growth. The National Environment Management Authority (NEMA) continues to foster a green development pathway for Kenya. Maasai Mara University being a public university in Narok County it is expected to influence the community in knowledge sharing and dissemination on various research outputs. Through the establishment of the Center for Innovation, New and Renewable Energy, Maasai Mara University has facilitated the use of green energy. With only $46 \%$ of the Kenyan households having access to electricity, $54 \%$ of the population make use of nonrenewable energy sources for their daily needs. This means that most Kenyans continue to use non-renewable energy presumably due to lack of knowledge for an alternative. Narok County counted as a marginalized county in Kenya, benefited from International Development Association (IDA) where \$150 million grant was issued via the World Bank to promote access to modern energy. The Kenyan government through Rural Electrification Programme, has come up with the National Electricity Policy aimed at increasing the deployment of renewable energy. With such concerns, there is need to determine whether or not universities actualize their role of sharing information including that of renewable energy to the community. This study adopted a descriptive survey design. The target population was 11,776 households in Narok Town sublocation. With the use of stratified sampling technique, the sample size used in the study was 4122 households being $35 \%$ of the number of households in the area. Primary data was collected using open ended and closed questionnaire. The study revealed that $56.6 \%$ of the Narok Town residents were not aware of renewable energy sources. Only $17.6 \%$ of the households were able to be influenced on green energy choices by Centre for Innovation, New and Renewable Energy at Maasai Mara University. The study further indicates that $47.9 \%$ of the households would prefer seminars as the appropriate method. For universities to share knowledge on renewable energy. The study therefore recommends that Institutions of higher learning should be on the forefront to influence green energy to surrounding communities. Keywords: Universities; Knowledge Sharing; Renewable Energy; Maasai Mara University

DOI: $10.7176 / \mathrm{JETP} / 9-9-04$
\end{abstract}

Publication date: December $31^{\text {st }} 2019$

\section{Introduction and Background of the study}

Education and research are largely recognized in a number of Sustainable Development Goals (SDGs) where universities are expected to address such issues. However, it should be noted that the contribution of universities is broader as they are also expected to influence and support implementation of any SDG goal. As the world aims to lower the rate of carbon energy emissions, higher education will play a key role. In Africa, universities shun away from offering programs based on renewable energy. They educate students on how they can be competent professionals in other fields. With universities being a cradle for knowledge with an eye for future implications, it is expected that they can train, research and offer extension services that are necessary to foster the use of renewable energy. No single energy source can meet all the energy needs. In Kenya, tough economic conditions make a lot of her citizens opt to use a non-renewable source of energy due to its affordability and accessibility. Very little concern has been given to safeguard the environment from future degradation.

According to Warutere and Toure, (2015), Kenya is considered as one of the fast-growing economies in Africa. This implies that it is expected to be susceptible to emerging technologies such as the use of renewable energy for the energy needs of her citizens. While the Kenyan power sector is a true success story in sub-Saharan Africa, only $46 \%$ of the Kenyan households have access to electricity. This means that $54 \%$ of the rest of Kenyans still use energy sources that harm the environment (Power Africa, 2015 pg. 4). As a developing country, a high level of poverty and low levels of human development increase the vulnerability of Kenya Arid and Semi-Arid Lands (ASALs). Climate change has been real in Kenya with rainfall patterns greatly affected, for instance, the total population of large grazing wildlife species in Kenya's ASALs reportedly declined by $61 \%$ between $1977 / 78$ and 1994/96 (Njoka et al., 2016 pg. 12). Even with consequences that result from environmental degradation having being witnessed by Kenyan citizen's first-hand, such issues are usually politicized which makes saving the environment and protecting future generation become difficult. National Environment Management Authority (NEMA) advises the government on legislative and other measures for management of the environment and ensures the environment is conserved. Kenyan universities are left with the responsibility of influencing the 
community to result to clean ways to generate and use energy.

Kenya has set the 'Big Four' Agenda that include (i)universal healthcare (ii)improve manufacturing sector to create more jobs for its citizens (iii)create affordable housing (iv) enhance food security by 2022. Successful implementation of the Big Four Agenda will foster a green Kenya especially on food security where the environment will be of concern. According to Parliamentary Budget Office, (2018) continuous consultation on both national and county governments for effective implementation of the Big Four Agenda. East African Community (EAC) Vision 2050 supports regional integration by better assimilation of Sustainable Development Goals (SDG) from the Common African Position on the Post-2015 development agenda for African continent to independently cope with emerging global development challenges (EAC, 2015). By doing so, effective conservation of resources will be enhanced for improved environmental management.

AUC First Ten Year Implementation Plan of Agenda 2063 (2013-2023) of which environmental sustainability and climate resilient of communities are part of the agenda in the eight agendas as declared in the Golden Jubilee Summit of the Union (AUC,2015). In realization of the development plans, the Kenya's Millennium Development Goals is expected to be realized. The goals plan to eliminate poverty and hunger, provide universal primary education, lower HIV/AIDS, reduce child mortality, gender equality and enhance environmental sustainability.

\section{Universities and renewable energy}

Globally, there are various initiatives on renewable energy; there was the World Future Energy Summit (WFES), which took place in the United Arab Emirates capital Abu Dhabi from 15-17 January 2012 that brought together business leaders, government representatives, non-governmental organizations, teachers and students. The main goal of the summit was to educate participants on how to attain green environment. According to (IISD, 2012) Professor Dr Kornelis Blok stresses on a broad-based education on renewable energy and climate policy that pulls back the use of renewable energy by the society. Universities are educating on renewable energy and train students to work on renewable areas. Blok (IISD, 2012.), encourages on continuous training on already established professionals on renewable energy especially on new technologies. In Kenya, some of Universities have started offering programs on renewable energy. Moi University is now accredited trainer for renewable energy having professional certification program (REP) intended to train on application of renewable energy and assessment of renewable energy. Kenyatta University has a department on energy engineering that addresses energy and environmental issues through training and research.

While Kenya is divided in forty -seven county governments, Narok County is among the counties that fall under Arid and Semi-Arid Lands. Due to the economic challenges and the grave climate pattern in the area, most residents are left with no choice but to result to use sources of energy which is not favourable to the environment. While the local government and the national government strive to ensure that the living standards of the urban population, as well as the rural population of Narok country is decent, little effort is given to realize Kenya's dream to be fully powered by green energy by 2020 (Wood, 2018). Maasai Mara University is a local university in the region, it is expected to alleviate the environmental harm by influencing the surrounding community to use renewable energy for their daily energy needs. Maasai Mara University is geared towards making Kenya a country that has a concern about the safety of the environment. With its Centre for Innovation, New and Renewable Energy, the university aims "to set up a hub for excellence in research into; materials, renewable energy, technology and innovations at the university in view of producing tangible products, alternative green Energies, guide, manage and improve on the use of the existing energy; train, Research in Frontier areas of Science and Technology, and producing consumable innovative energy products and ideas ready for implementation in view of reducing emissions and costs." (Maasai Mara University, 2019)

With the realization that Kenyan universities such as Maasai Mara University have the technology and the capacity to create new innovation and foster renewable energy uses, the challenge remains how has the university shared the knowledge to the local community (EUEI PDF, 2014). This study takes a look at the urban population in Narok North Constituency Specifically Narok town on their energy uses and how Maasai Mara University as impacted knowledge on renewable energy. This study will assist to streamline the Kenyan government efforts to promote the use of renewable energy. Through the findings of the study, the government is likely to fund local universities to enable the development of new innovation on green energy and its uses in a bid to expedite the green power dream and also protect the environment which as it stands it is not out of harm's way.

\section{Statement of the problem}

The energy sources in Kenya consists of imported fuels and renewable energy such as biomass, hydro, geothermal, solar and wind. Hydroelectricity accounts for $52.1 \%$ of energy production, geothermal accounts for $13.2 \%$, while the rest of renewable energy shares the remaining percentage (Hivos, 2019). However, hydroelectricity in Kenya is considered as renewable energy but the fact that trees have been destroyed makes it be non-renewable as less rainfall is registered to produce optimal electricity generation. Nationally, $69 \%$ of all households use firewood for cooking (Nerini, Ray and Boulkaid, 2017). This makes it dangerous for the dry lands and wetlands as trees are 
responsible for the preservation of the ecosystem. The Kenya Power and Lighting Company (KPLC) which is the national electric supplier in the country only produces $5 \%$ of energy from renewable sources to the national grid (Hivos, 2019. There is a significant potential for Kenya to produce energy from alternative renewable energy sources such as wind, liquid petroleum gas (LPG), biogas, briquettes, solar, Hydrogen and fuel cells among others (Pundo and Fraser, 2006).

According to Ntanos et al., (2018), social acceptance of green energy use at both national and local level is depended on the attitude of the community. Each part of human development requires some form of inputs were in the early stages of human existence soil water and air was essential. In the contemporary world, the advancements in human developments make the new technique of harnessing and using energy become important. Locals although, they may not have the technical knowledge of renewable energy, they understand that harming the environment can through cutting down trees and use of fossil fuels for energy. According to a study conducted by Khambalkar, 2010, a significant number of people are aware of renewable energy. However, the problem remains the perception of its implementation. While the Kenyan government increases its awareness on the use of Liquefied petroleum gas (LPG) among other green sources, a lot of Kenyans who live on less than a dollar a day feel burdened on financial contribution towards lowering the harm of the environment through use of renewable energy (Olang, Esteban and Gasparatos, 2018).

When a look is taken at Narok country in Kenya specifically the residents of Narok Town, the concept of renewable energy becomes a challenge to them. Almost all of the Narok town residents use firewood as their main source of energy production for cooking. In addition, charcoal which is derived from tree cutting is also used for their energy needs. Most of the firewood charcoal that Narok Town residents use is from Mau Forest Complex. The effects have been a reduction of water levels of river Ewaso Ng'iro which render Narok town residents without water during dry seasons (Lanari et al., 2018). Efforts to bar people from encroaching the Mau Forest Complex has been met with political barriers thus thwarting the efforts to have sustainable energy production through renewable energy use. It should be noted that while it can be argued that firewood can be considered renewable energy, cutting down trees for energy uses without replacement makes firewood cease to be renewable.

It is presumed that with local universities' understanding of the importance of a green environment, they ought to influence the local community to adapt to green energy production and use. The effects of the environment in Narok town, as well as the whole country, has been felt with the prolonged dry seasons and shortened rainy seasons. People lack the necessary knowledge to avoid become victims of climate change by using renewable energy. Maasai Mara University, has downplayed its influential role to be able to equip Narok town with the necessary knowledge of renewable energy. The living standards of Narok Town residents is below average which means a search for information on renewable energy is not amongst their first priority but they believe something should be done about protecting the environment. When universities such as Maasai Mara University is able to relay knowledge and technical know-how in regards to renewable energy, it can supplement the Kenyan's government future vision of green energy production and use.

\section{Objective of the study}

The objective of this study is to establish the role of universities in sharing information on renewable energy to the community for Sustainable Development.

\subsection{Specific Objectives}

1. To establish sources of energy used in Narok County.

2. To ascertain level of knowledge shared on renewable energy in Narok County.

3. To recommend optimal ways on knowledge sharing on renewable energy in Narok County.

\section{Research questions}

1. What sources of energy used at Narok County?

2. Are Narok residents informed on renewable sources of energy?

3. How can knowledge be shared to Narok residents?

\section{Significance of the study}

The knowledge generated from this study shall contribute to the body of knowledge concerning the state of renewable energy use in Kenya specifically in urban population. Universities will be provoked to play their role of influencing the society vis-à-vis making the world sustainable for future generation. The study also seeks to seamlessly provide the Kenyan government with solutions to their efforts to foster green energy use in Kenya by funding Kenyan university to develop and expand their research and of new and innovative renewable energy for the local populations. Through the study, policy formulation regarding fostering renewable energy will be shifted towards ensuring that population is knowledgeable on green energy practices. 


\section{Research Methodology}

\subsection{Research design}

The study utilized a descriptive survey design because it is regarded suitable for providing accurate descriptive analysis of characteristics of the sample from the population (Mugenda and Mugenda, 2008).consequently, the study design was consequential because the data collected from the large group involved description of their attitude and actual experiences in their day to day energy consumption. The design was expected to deepen the understanding of the universities' impact in knowledge sharing on renewable energy for sustainable development.

\subsection{Study population and study sample}

The population of the study involved the urban population of Narok North constituency in Narok county Kenya. The study specifically concentrated on Narok Town sublocation with a total population of 42,505 residents (Kenya National Bureau of Statistics, 2009). Owing to the nature of the study on choices energy usage, the study population was household-based where Narok Town sublocation has 11,776 households (Kenya National Bureau of Statistics, 2009). The study used stratified simple random sampling to select respondents from 4122 households representing $35 \%$ of the households in Narok Town sublocation with a margin error of 5\% and confidence level of $95 \%$. The households were distributed in the following estates; Majengo, lenana, Total, Kamoja, and London. Data was collected by use of questionnaire. The data collected was edited and coded thematically and analyzed using the statistical package for the social sciences SPSS to generate descriptive statistics. The data collected was presented using tables, pie charts and bar graphs to summarize the data for ease of understanding.

\section{Research Findings and Discussions 8.1 Income in Monthly Basis}

The above diagram indicates the income levels of the study population. Households which earn above Ksh10,000 were the highest with 39.5\%. Those earning between Ksh10,000- Ksh15,000 followed with 24.1\%. respondents with a monthly basic income of between Ksh15,000- Ksh20,000 were 19.3\%. Only 17.1\% had a monthly basic income of above Ksh20,000.

The level of income determines the choice of energy usage. The higher the income the likely hood of people utilizing relatively expensive renewable energy. The data indicates that the majority of households in Narok Town survive with a meager earning of Ksh10,000. This means that their choice of energy usage is not renewable as it is cheap and easily available.

\section{Income in Monthly Basis}

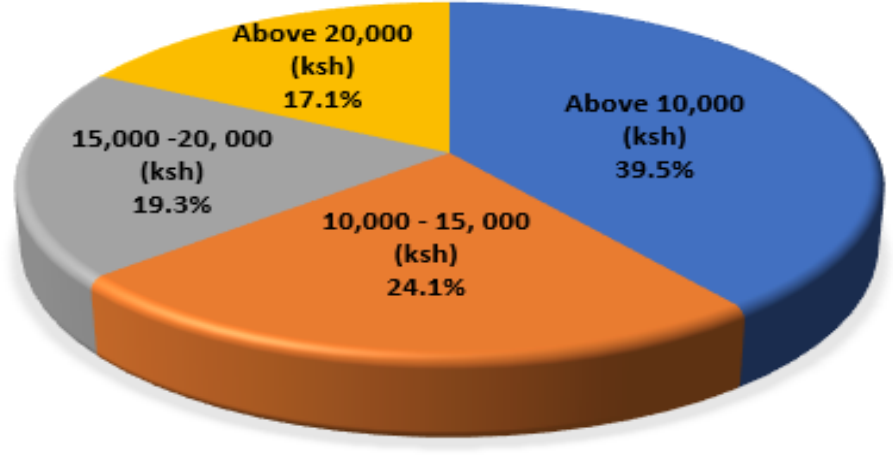

Figure 1: Income in Monthly Basis

\subsection{Type of Fuel Used for Domestic Purposes}

From the above table, the majority of the Narok Town households used LPG as their main source of domestic purposes with a percentage of $37.8 \%$. It was followed by charcoal which was $36.9 \%$. Some of the households who used firewood for the energy purposes were $14.9 \%$. Households which still use kerosene account for $8.6 \%$. Only $1 \%$ of the households used biogas while the usage of briquettes accounted for $0.1 \%$. 5 households representing $0.7 \%$ use Napier grass rhizomes for energy uses.

According to the findings, the respondents were allowed to choose more than one option for their energy uses. The table above shows that liquefied petroleum gas (LGP), charcoal and firewood are the main sources for energy used simultaneously. This means that in Narok Town sublocation, the sensitivities to sustainable energy use is not considered as an important element. With the majority of the residents using charcoal and firewood as part of the energy uses means that the environment is put at risk. Renewable energy such as biogas, briquettes and Napier grass rhizomes were only used by a few who cumulated to 14 households. 
Table 1: Type of Fuel Used for Domestic Purposes

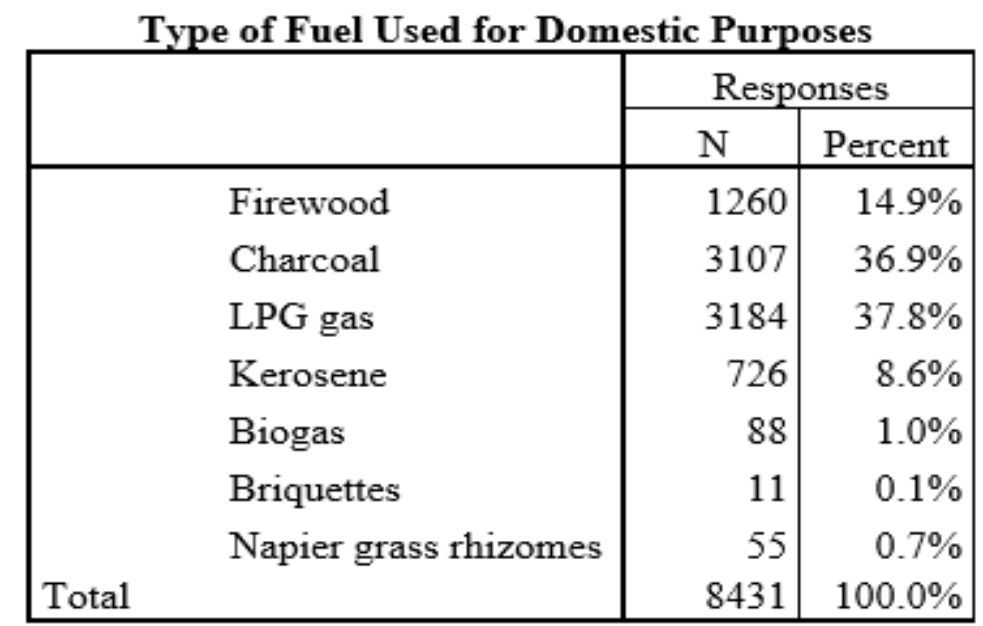

\section{3 Reasons for Choices of Sources of Energy}

It is evident from figure 2 above that $57 \%$ of the household uses their preferred energy choices because it is easily available. Those whose choice is influenced by affordability are $25.4 \%$. Only $0.5 \%$ of households use energy sources due to the influence of culture. $15 \%$ of the respondents assert that their energy choices are influenced by the ease of use. Only $2.1 \%$ of the respondents' energy choice is determined by their ability to conserve energy.

The study aimed to determine how energy conservation and sustainability play a role in the determination of energy choices. Very few respondents were knowledgeable of the energy conservation facets that are important when selecting energy sources. Most of the respondents' choices of energy were determined by the availability and affordability which are factors that do not contribute to sustainable energy choice.

\section{Reasons for Choices of Sources of Energy}

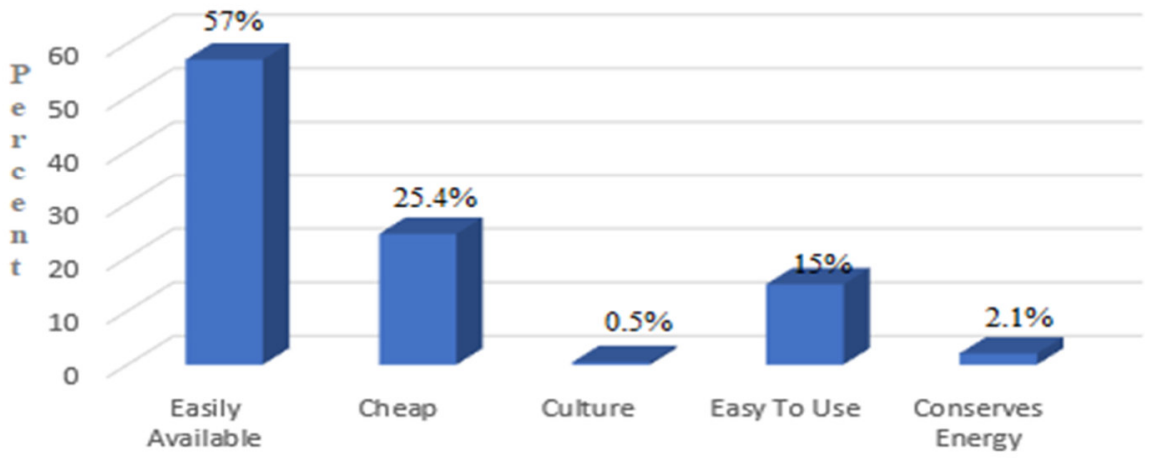

Figure 2: Reasons for Choices of Sources of Energy

\section{4 Source of Knowledge on Energy Choices}

The table below shows that $67.2 \%$ of the households learned about their energy choices from family. $23.0 \%$ of the respondents knew about their energy sources through their friends. Only $3.7 \%$ of the households were able to determine the energy sources from knowledge disseminated from the university. Those who learned from the internet and other sources such as local meetings make up $6.1 \%$.

The study wanted to determine to what extent that Maasai Mara University has influenced the energy source choice for its surrounding community. It appears that family plays a pivotal role in teaching and influencing on what type of energy can one use. Knowledge from friends also assists in the same purpose. University plays a minimal role in making sure that people can choose sustainable energy choices. The prolific information on the internet which is sometimes unverified is being used by people to choose their type of energy choices. 
Table 2: Source of Knowledge on Energy Choices

\begin{tabular}{|l|r|r|}
\hline & Frequency & Percent \\
\hline Family & 2768 & $67.2 \%$ \\
Friends & 947 & $23.0 \%$ \\
Seminars & 154 & $3.7 \%$ \\
Social Media & 253 & $6.1 \%$ \\
Total & 4122 & $100.0 \%$ \\
\hline
\end{tabular}

\subsection{Influence of the Centre for Innovation, New and Renewable Energy on energy choices}

The study found that $94 \%$ of the respondents were aware of the existence of Maasai Mara University. Only $17.6 \%$ of the households were influenced by the Maasai Mara University-based, Centre for Innovation, New and Renewable Energy.

The data provided shows that despite the Centre for Innovation, New and Renewable Energy making efforts in developing renewable energy. It has made little effort in disseminating its knowledge in the surrounding community. Its little influence is because it has not marketed itself enough to the University fraternity who are expected to spread the message to the outside community.

\section{Influence of the Centre for Innovation, New and Renewable Energy on energy choices}

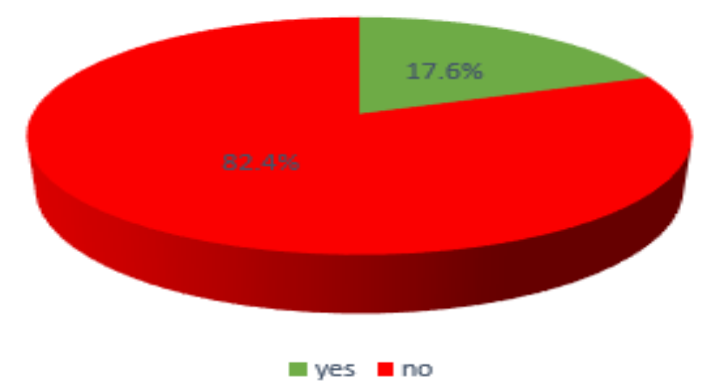

Figure 3: Influence of the Centre for Innovation, New and Renewable Energy on energy choices

\subsection{Challenges experienced in Getting Information in Relation to Renewable Energy}

The results presented in Table 3 below shows a lack of awareness of renewable energy is the biggest challenge they experience in getting information concerning renewable energy with a percentage of 56.6\%. The findings indicate that those who are interested but lack the searching skills to get information are $16.9 \%$. Those who claimed that Maasai Mara University does not offer support in providing knowledge in renewable energy were $12.6 \%$. Only $13.9 \%$ asserted that that information on renewable energy was not their priority.

The findings show that most of the residents do not know what renewable energy is hence do not develop the need to search on it. Those who wished to find information on renewable energy did not have enough skills in information searching. This attributed to the low level of education of the lack of facilities such as computers. Maasai Mara University is not doing enough in its extension services to ensure that the community surrounding it knows renewable energy. The fact that few respondents suggested that information on renewable energy is not a priority means that most Narok North residents would like to know about renewable energy. 
Table 3: Challenges experienced in Getting Information in Relation to Renewable Energy

\begin{tabular}{|l|r|r|}
\hline & Frequency & Percent \\
\hline Lack of awareness & 2335 & $56.6 \%$ \\
Lack searching skills & 696 & $16.9 \%$ \\
The university does not offer support & 518 & $12.6 \%$ \\
Information on renewable energy is & 573 & $13.9 \%$ \\
not a priority & 4122 & $100.0 \%$ \\
Total & & \\
\hline
\end{tabular}

\subsection{Strategies for Knowledge Sharing on Renewable Energy}

The results presented in figure 4 below shows that 49.7 of the respondents would prefer seminars as their method in which the knowledge on renewable energy would be shared. $24.6 \%$ believe that posters are the most effective way of sharing knowledge. Those who prefer to attend talks on renewable energy were $15.5 \% .5 .1 \%$ find it very necessary when programs on renewable energy are introduced in learning institutions as a way of knowledge sharing. When it comes to educational forums such as career days $4 \%$ believe that during such fora is the best way to share knowledge on renewable energy. Only $1.1 \%$ felt that university open days would serve best as a strategy for sharing knowledge on renewable energy.

From the findings, getting to have a sit down through seminars with Narok Town residents is the best way to share information on renewable energy. Seminars work the same way as Environmental talks. Posters are the most conventional way of sharing knowledge but usually look less serious. When people are educated solely on renewable energy, they are likely to share knowledge faster in the family setups. Educational fora and university open days are the least preferred strategies for knowledge of renewable energy.

\section{Strategies for Knowledge Sharing on Renewable Energy}

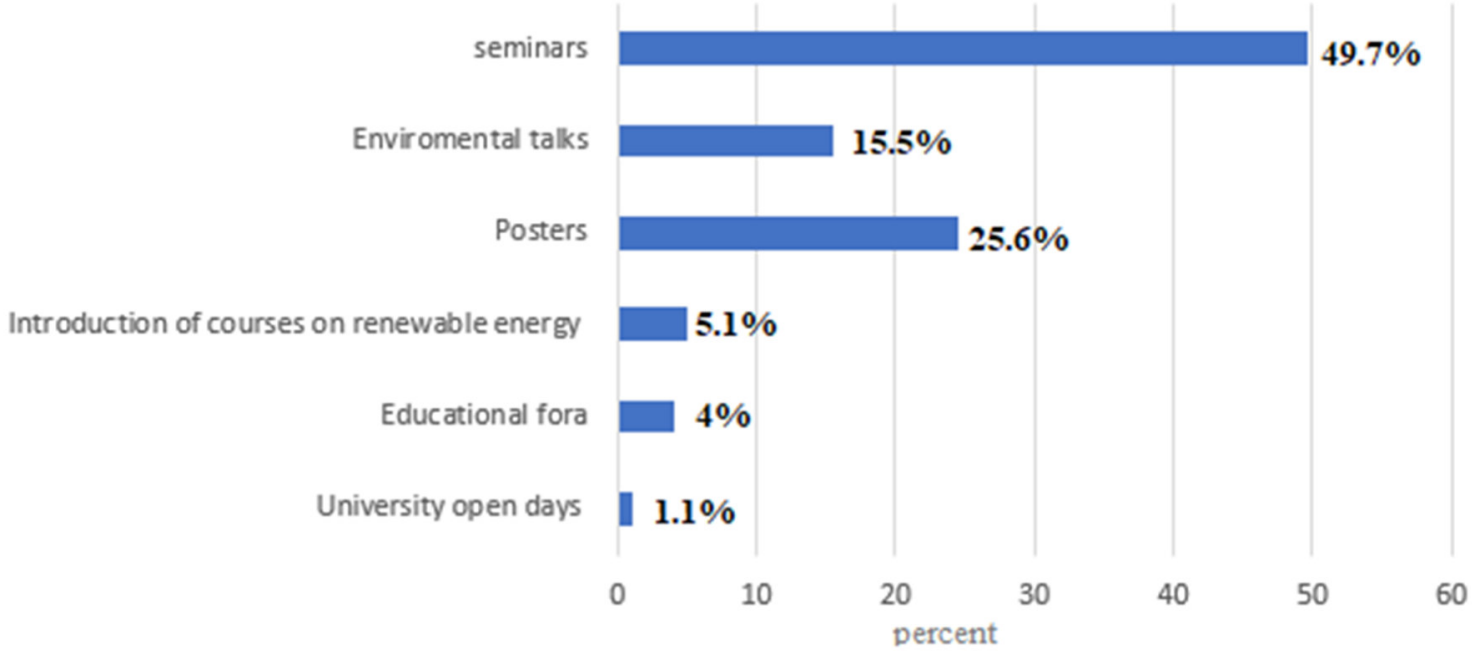

Figure 4: Strategies for Knowledge Sharing on Renewable Energy

\section{Conclusion}

The study determined that there is a low impact of universities in using their extension services to influence the community in opting renewable energy. Despite the existence of the Centre for Innovation, New and Renewable Energy at Maasai Mara University, the surrounding community are still using firewood and charcoal for their various energy uses. A university is expected to use its research to influence the community. However, the role has been left to families which have played a major role in dictating the choices of energy sources. To raise awareness, the university is expected to utilize seminars where they can engage the community and advise on sustainable energy choices.

\section{Recommendations}

It was established from the study that Maasai Mara University has not contributed to knowledge sharing on renewable energy to the surrounding community. In this regard, it is recommended that a family-based seminar 
should be considered in sharing information on renewable energy for sustainable development. The energy sources such as briquettes produced by the Centre for Innovation, New and Renewable Energy should be commercialized. Maasai Mara University should increase more funding to the Centre to give it the muscle to conduct outreach and be able to come with innovative renewable energy sources. The study further recommends that university programs tailored to sustainable development should be introduced to foster innovation in renewable energy.

\section{References}

African Union Commission (AUC). (2015). Agenda 2063 The Africa We Want: A Shared Strategic Framework for Inclusive Growth and Sustainable Development, First Ten-Year Implementation Plan 2014 - 2023. The African Union Commission.

EAC. (2015). East African Community vision 2050: regional vision for socio-economic transformation and development. The East African Community. Retrieved from http://repository.eac.int/handle/11671/567

EUEI PDF. (2014). Higher Education for the Renewable Energy Sector in Africa. EU Energy Initiative Partnership Dialogue Facility. $\quad$ Retrieved from http://www.eueipdf.org/sites/default/files/field_publication_file/RECP_HE_Workshop_Kigali_-_Conclusions_2014-0716 final.pdf

Hivos (2019). Kenya: Energy Profile. Hivos. Retrieved from https://www.hivos.org/sites/default/files/kenya_profile.pdf

IISD. (2012). World Future Energy Summit Bulletin. International Institute For Sustainable Development (IISD), 187(2), 1-6.

Kenya National Bureau of Statistics, 2009. The 2009 Kenya Population and Housing Census. Kenya National Bureau of Statistics

Khambalkar, V. P., Katkhede, S. S., Dahatonde, S., Korpe, N. D., \& Nage, S. M. (2010). Renewable energy: an assessment of public awareness. International Journal of Ambient Energy, 31(3), 133-142.

Lanari, N., Schuler, R., Kohler, T., \& Liniger, H. (2018). The Impact of Commercial Horticulture on River Water Resources in the Upper Ewaso Ng'iro River Basin, Kenya. Mountain research and development, 38(2), $114-$ 125.

Maasai Mara University. (2019). Maasai Mara University - Knowledge for prosperity - Directorate of Innovation, New and Renewable Energy. Retrieved 12 August 2019, from https://www.mmarau.ac.ke/ourprogrammes/schools-campuses/tourism-natural-resource-mngt/23uncategorised/index.php?option=com_content\&view=article\&id=27:clubssocieties\&catid $=15:$ students $\&$ Itemid $=191$

Mugenda, O.M., \&Mugenda A.G. (2008). Research methods: qualitative and quantitative techniques, Nairobi: Acts Press

Nerini, F. F., Ray, C., \& Boulkaid, Y. (2017). The cost of cooking a meal. The case of Nyeri County, Kenya. Environmental Research Letters, 12(6), 065007.

Njoka, J., Yanda, P., Maganga, F., Liwenga, E., Kateka, A., \& Henku, A. et al. (2016). Kenya: Country situation assessment. Research for climate-resilient futures.

Ntanos, S., Kyriakopoulos, G., Chalikias, M., Arabatzis, G., \& Skordoulis, M. (2018). Public perceptions and willingness to pay for renewable energy: A case study from Greece. Sustainability, 10(3), 687.

Olang, T. A., Esteban, M., \& Gasparatos, A. (2018). Lighting and cooking fuel choices of households in Kisumu City, Kenya: A multidimensional energy poverty perspective. Energy for Sustainable Development, 42, 1-13.

Parliamentary Budget Office. (2018). Eye on the "Big Four," (11), 65. Retrieved from http://www.parliament.go.ke/sites/default/files/2018-09/Budget Watch 2018.pdf

Power Africa. (2015). Development of Kenya's power sector 2015-2020. Power Africa.

Pundo, M. O., \& Fraser, G. C. (2006). Multinomial logit analysis of household cooking fuel choice in rural Kenya: The case of Kisumu district. Agrekon, 45(1), 24-37.

Warutere, P., \& Toure, A. (2015). Kenya Among the Fastest Growing Economies in Africa. Retrieved from https://www.worldbank.org/en/news/press-release/2015/03/05/kenya-among-the-fastest-growingeconomies-in-africa

Wood, J. (2018). Kenya is aiming to be powered entirely by green energy by 2020. Retrieved from https://www.weforum.org/agenda/2018/12/kenya-wants-to-run-entirely-on-green-energy-by-2020/

Yamane, Taro. (1967). Statistics: An Introductory Analysis, 2nd Edition, New York: Harper and Row. 